
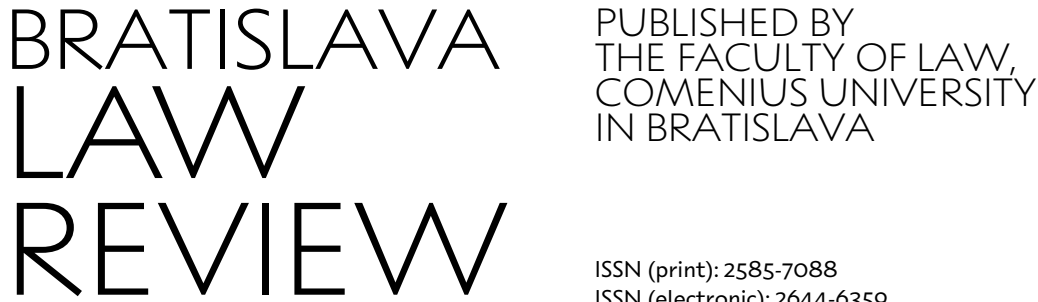

ISSN (print): $2585-7088$

ISSN (electronic): 2644-6359

\title{
INDUSTRY 4.0, LEGAL PROTECTION OF THE EMPLOYEE AND INTERCULTURAL IMPACT OF LABOUR MIGRATION / Aleš Kainz
}

\author{
Aleš Kainz \\ Prague University of Economics and \\ Business, Faculty of International \\ Relations, Department of Business \\ and European Law, \\ Nám. Winstona Churchilla 1938/4, \\ 13067 Praha \\ Czech Republic. \\ kaia02@vse.cz \\ ORCID: 0000-0003-3486-0052
}

\begin{abstract}
Industry - Industry 4.0 [14.0] is the main topic of discussions and proposals for innovative changes. In the last five years, inside industry sectors took place the intellectual clashes among digitisation, robotisation and automation. These concepts have been combined with performance, efficiency gains, steady economic growth, employment, labour migration, and increasing labour productivity in all managerial or economic forums. In particular, the European Union [EU] is one of the foremost leaders in improving workforce quality, given the increasing share of robotics and automation. The competitive pressure, beset on individual EU member states by countries with low-cost labour, is increased by assessing economic growth, increasing labour productivity, and setting social-law standards in the EU.

On the other hand, increasing the automation of production plants leads to increased employment pressure and contributes to managed labour migration. This migration is mainly about the pressure on competencies, quality, number of employees and the negative development of the demographic curve in the EU. All this reflects the demand for more robust legal protection for workers in the field of social assistance and legal regulations generally linked to a rapid change in labour market conditions. The resulting mix will have a significant impact on the economy's performance and competitiveness.
\end{abstract}

Key words: Industry 4.0; Employment protection legislation; Productivity; Labour law and migration; Intercultural behaviour JEL Classification: J48, K31

\section{Suggested citation:}

Kainz, A. (2021). Industry 4.0, Legal Protection of the Employee and Intercultural Impact of Labour Migration. Bratislava Law Review, 5(1), 137-144. https://doi.org/10.46282/blr.2021.5.1.219
Submitted: 05 January 202 Accepted: 13 March 2021 Published: 30 June 2021

\section{INTRODUCTION}

In a globalised, economically connected and knowledge-based society, we are talking about an industrial revolution of a new type. Historically, we can define the three essential milestones: the first industrial revolution starting up sweatshops and machine drives by natural elements. The second industrial revolution is introducing mass production using electricity. Finally, the third industrial revolution connected the automation of production controlled by electronics and computing. All industrial revolutions were closely related to man, mover, or instrument for introducing change and 
were associated with a jump in labour productivity, economic growth, well-being, and scientific and technological progress.

The 14.0, as first presented by the German Institute for Research and Development and comprehensively supplemented at the Hannover Engineering Fair 2011 (Kawano, 2015), is significantly different. We are talking about the fourth industrial revolution connected with cyber-physical systems (Mařík, 2016) playing a significant role. These systems should represent a decentralised intelligence to help complete networked intelligent objects and independent control systems with real and virtual interdependence, i.e., mutual exchange of information and decision-making independently of users (Tomek \& Vávrová, 2017). The very nature of such management systems is independent of external interventions, i.e., user influence. Is it the purpose of scientific and technological progress to help the human community move its standard of living forward?

Labour law aims to reduce or blunt social disparities between social classes, i.e., establishing a balanced status between employee and employer status (Kratochvíl, Cícha, \& Jurča, 2017). We ensure such a balance, as the superior protection, used when we look at employees as the weaker side of employment relations. We find the soft side mainly insubordination or within the basic need to have a job to meet our family's needs.

The concept of labour migration based on the combination of the words migration and work, where migration is understood as a change in the place of long-term residence, and we do not distinguish, in this case, for what purpose it occurs. It is the decision of an individual or group to change their residence place without changing their nationality. If we are talking about changing long-term residence by reason to look for other working conditions, it is necessary to apply the economic paradigm of the invisible hand of markets; competitive advantage and the associated maximum usability of the offered labour force. We can follow the law of supply and demand. It ensures the movement of the workforce and directs it to the places of its best use (Dušek, 2020).

The impact of intercultural behaviour on contemporary society is evident. This obviousness is perhaps why it is not often considered one of the fundamental factors in labour law and labour migration. The history of intercultural relations comes back to the emergence of the human community. Still, it has never reached the level of influence and greatness in today's globalised world. Previously, only people from specific fields of human activity or condition had the opportunity to contact foreign cultures. Today, even the most isolated and marginalised groups of people can communicate around the world. The intercultural connection has become a reality of everyday life for almost all of us (Kainz, 2012).

\section{THEORETICAL BACKGROUND}

Industry 4.0 is called the beginning of a new industrial revolution. The fourth industrial revolution concept has been directly connected to the German Ministry of Industry initiative. The basic idea is the digitisation and robotisation of all processes. Based on independently functioning cyber-physical systems which can self-learn. This system can learn more and improve itself (Rohrbach, 2017) in functional units that can work effectively without human hand intervention. Furthermore, the internet of things creates an interconnected or mutually informed technology network by connecting machine control systems to the internet (Floerkemeier, Langheinrich, Fleisch, Mattern, \& Sarma, 2008). 
Labour law, its modern evolution, is related to the downfall of the feudal order and the rapid commencement of capitalism. The rapid onset of the Industrial Revolution and the development of related technologies, in the period of the 18th - 19th century, showed the need to describe the relationships more accurately between essential economic resources, as capital and work, where are the employer - the owner of capital and the employee - the bearer of the work. The disequilibrium of employer-employee relations, linked to the employee's dependence on remuneration for the work done, has proved to be further unsustainable. (Löwisch, Caspers, \& Klumpp, 2019).

Labour migration exists all the time and in all regions of the world. The retrieval for more favourable jobs is still the primary motivation for migration today and explains why working migrants account for a significant share of international and internal migration populations. In addition to work, other reasons for migration include conflicts, wars, political persecutions, family reunifications, educational opportunities, and climate changes.

The intercultural background must combine preparation for business meetings and precisely identify cultural differences and behaviour stereotypes. We can apply and appropriately use the courtesies rules and regulations of trade etiquette, which can help provide reasonable conditions for the success and improvement of business communication efficiency. Cultural competence refers to the ability to cooperate effectively with people of different cultures. This ability consists of four parts: the first two parts deal with the first stage (self-cooperation). They are based on awareness of one's cultural view of the world and attitudes towards cultural stereotypes and recognising cultural differences. The other two parts relate to the interpersonal and organisational level. It is about knowledge of different cultural customs and worldviews and knowledge of the skills that intersect with cultures.

Within this framework, cultural competence development represents the ability to understand, interact with, and effectively interact with people across cultures. When working in a global business environment, knowing the impact of cultural stereotypes and cultural differences is key to achieving international business success. Improving cultural awareness helps build international competencies and understand the business partners behaviour across the global business spectrum.

\section{RESEARCH METHODOLOGY}

The paper is drafted as a theoretical essay or essay, in the sense of AngloAmerican scientific research (Werro \& Dedek, 2017). Comparing current knowledge of the topics mentioned above looks for weak and healthy places in their links. The author uses an analytical-synthetic approach to link subtopics and adds his view of possible future results and solutions. The author's synthesis theoretical framework describes particular topics and an effort to connect them to increase familiarity with the Czech Republic subject.

\section{THEORETICAL RESULTS}

Despite many positive expectations, increasing labour productivity, limiting the impact of human work, reducing costs, increasing production, reducing error rates and increasing work safety, a view of the socio-economic effect of robotisation and automation on the labour market is essential. This kind of doubt has accompanied the human race since ancient times when Aristotle writes in his Politics, "A servant in art and 
craft is a kind of instrument...and therefore a slave is a kind of soulful instrument. Instead of many tools, it is an instrument if every tool could perform its work when ordered or see what to do in advance... if thus shuttles wove and quills played the harps of themselves, master-craftsmen would have no need of assistants and masters no need of slaves". (Aristotelés, 2009), any automation would lead to job losses. This idea shared in many economic theories, such as the J.M. Keynes theory. The IP 4.0 is a revolutionary change of individual working or production processes with the help of robots, independent control and automatic units controlled by computers and the interconnection of their "sensory organs" using the internet of things. Each occupationally qualified population, i.e., a group affecting economic consumption, given their income, is divided into two primary groups: a group of skilled workers and a group of less qualified workers. Suppose we improve the technology (A2) suitable for less-skilled workers to the technology (A1) suitable for a group of qualified people only. In that case, increasing the relative number of qualified employees will reduce their wages and decrease the relative number of less qualified workers in the short term, within three years.

The risks arising from IP 4.0, which threaten jobs, will arise even without individual companies or 'states' help. From the point of view of neoclassical theory, automation should not affect the global or closed economy; that is, the Czech Republic, with a small open economy, being at risk. Nevertheless, on the other hand, we cannot ignore 'digitalisation's potential to create new jobs and business opportunities. In this case, the ratio created to extinct jobs is two to five (Frey \& Osborne, 2017).

The EU labour law on the subsidiarity principle belongs under the responsibility of every national law system. The fundamental pillars are the Fundamental Charter of Rights and Freedoms, the European Convention for the Protection of Human Rights, and the European Social Charter. The EU legislative process undoubtedly influences the systems of law, and its observance is under the supervision of the European Commission and the European Court of Justice (Steiner \& Woods, 2009).

In the Czech Labour Law, the central concept is not an employment contract or dependent work independently, but a labour-law relationship strongly linked to dependent work performance. The performance of the dependent activity is further divided into individual and collective. Individual activities are significant for Industry 4.0. According to the history of industrial revolutions, this is the 'employer's investment activity and the associated job losses. The point is to find a balance between working 'relationships' flexibility and an effort to ensure the 'employee's social security to the 'employer's greatest possible freedom in employment relations. A database of Indicators of the Organisation for Economic Cooperation and Development [from now on referred to as the OECD], the so-called EPL index, "Employment protection legislation - Legal protection of employment" is used for the necessary comparison and research of the readiness of the legal system in the field of labour law. The research methodology based on OECD research measured the strictness of protecting 'workers' rights and determining its direct impact on the labour market. The EPL is described for each OECD country using 21 points divided into three primary areas; 1 . Protection of long-term employed workers against individual redundancies, 2. Regulation of temporary, short-term forms of employment and 3. Specific requirements for collective redundancies. In 'today's scientific world, two different mainstreams of perceptions clash with the impact of strict legislative protections on unemployment dynamics. On the one hand, they are opinions that confirm the mutual influence of the two concepts (Barbieri \& Cutuli, 2016; Heyes \& Lewis, 2014), and on the other hand, some views reject that influence (Avdagic, 2015; Schhmann, 2014). 
If we focus on further developments, the forecasts show that because of unequal demographic developments and significant global labour market disparities, supply and demand for labour migrants could continue to increase, contributing to increased migratory flows. Considerable attention has been paid to why labour migration appears to be associated in some cases with positive development outcomes, but not in others, and which policies can help maximise the benefits of migration while minimising its costs. The scientist debates over the impact of migration on the 'economy's development reflected in many theoretical models and empirical research describing labour migration. Simple models try to describe and explain the reasons why people move from place to place. The pull factors encourage people to move from one area to another. The push factors are reasons for unfavourable conditions in areas where people live and encourage them to emigrate.

\section{THEORETICAL PROPOSALS}

A. The proposed solution and the inevitability are to increase expenditure on education and science to at least the EU28 average, from the current $1.94 \%$ of GDP - 2020 to $2.5 \%$ of GDP.

B. To prepare targeted legislation changes, especially in the Constitution, the Electoral Act, the Act on the Residence of Foreigners in the Territory of the Czech Republic and the Act on Citizenship. Their correct intention can influence and manage the process of who can enter or legally reside in the host country, when his family can move in and under what conditions, and who can obtain citizenship of the country or how to obtain the right to vote and therefore have a profound impact on social norms, values and institutions.

C. However, it can be generalised that the Union does not have exclusive competence in labour law. This legislation still belongs to the individual Member States and is influenced through EU policy by primary law, i.e. the directives adopted. In the field of labour, migration it is necessary to divide legislation into existing, touching and applicable directly (in the Czech Republic, e.g. Act No. 326/1999 Coll. on the Residence of Foreigners in the Czech Republic) and relevant indirectly (the Constitution, the Basic Charter of Rights and Freedoms, Social Security, Taxes, etc.). Within the basic principles of law, it is primarily about protecting personal rights, the safety of the labour migration process and legislation to promote labour migration.

D. If somebody has practical experience in employing EU, EEA workers and sending our workers abroad, this is an area that is not sufficiently well processed in the Czech literature. The author thinks the MPO published one more practical brochure, but it is not an "explicit science". Legal literature still describes the judgments of the Court of Justice of the EU, to a great extent, without focusing on current developments. Moreover, it is often an academic treatise on the law, but no longer on the extent to which it is applied or enforced. Here, therefore, the author certainly sees considerable potential for further development of the topic. For example - which countries create more suitable conditions for labour migration, and which countries are the architects of obstacles? In practice, from the point of view of companies, sending "employees" means something completely different from harmonising legislation at the EU/EEA level for officials in Brussels. 


\section{CONCLUSIONS}

Combining the IP 4.0 themes, cultural relations with the legal protection of employees and labour migration are currently mainly political topics. In the 'writer's opinion, it is necessary to seriously start looking at their labour legislation effects. After comparing available ideas and articles, the Czech Republic is ready to deal with the situation, especially in individual working relationships. However, the author does not think that is entirely true. It is all about coping with the supposed pressure on unemployment and a better-skilled workforce. 'Rohrbach's research (2017) shows that IP 4.0 will affect $19 \%$ of German companies within two years, $53 \%$ of companies within five years and $77 \%$ within ten years. The interdependence of our economies is a determining prerequisite for following a similar scenario in the Czech Republic.

According to the resolution of the Government of the Czech Republic (Vláda ČR, 2016), IP 4.0 is here, and we must be prepared; let us invest in new technologies, change school policy, science, put more money into "meaningful" research. Let us support retraining today of qualified employees at the age of 25-54; let us identify areas and prepare retraining courses. In the legal field and from the point of view of labour legislation, we need to work intensively on more flexible individual relations. The foreign 'workers' site is limited to general employment and specialists such as doctors and researchers. Above all, in the areas of part-time work, the conclusion of atypical employment contracts and the creation of shared employment relationships, we must find a familiar and workable solution. Efforts to understand the differences in the legal and cultural values of newly arrived workers are entirely disappearing. Their understanding and preparation in this area will be the fatal difference between success and failure in their integration-the possibility of successful self-enforcement in the labour market. Simplicity in employing foreign labour and reducing bureaucracy has been discussed for the last few years. We are members of the Visegrad group, where this platform directly encourages adopting common strategies in all the areas mentioned above. If we do not adapt, we will remain dragged out of economically more robust or faster-responding states.

\section{BIBLIOGRAPHY:}

Aristotelés. (2009). Politika (3rd ed.). Praha: Rezek.

Avdagic, S. (2015). Does Deregulation Work? Reassessing the Unemployment Effects of Employment Protection. British Journal of Industrial Relations, 53(1), 6-26.

Retrieved from https://doi.org/10.1111/bjir.12086

Barbieri, P. and Cutuli, G. (2016). Employment Protection Legislation, Labour Market Dualism, and Inequality in Europe. European Sociological Review, 32(4), 501-516. Retrieved from https://doi.org/10.1093/esr/jcv058

Dušek, J. (2020). Moderní personální management: trendy a výzvy. České Budejovice: Vysoká škola evropských a regionálních studií, z.ú.

Floerkemeier, C., Langheinrich, M., Fleisch, E., Mattern, F. and Sarma, S. E. (eds.). (2008). The Internet of Things: First International Conference, IOT 2008, Zurich, Switzerland, March 26-28, 2008, Proceedings (Vol. 4952). Berlin, Heidelberg: Springer Berlin Heidelberg. Retrieved from https://doi.org/10.1007/978-3-54078731-0

Frey, C. B. and Osborne, M. A. (2017). The future of employment: How susceptible are jobs to computerisation? Technological Forecasting and Social Change, 114, 254-280. Retrieved from https://doi.org/10.1016/j.techfore.2016.08.019

Heyes, J. and Lewis, P. (2014). Employment protection under fire: Labour market 
deregulation and employment in the European Union. Economic and Industrial Democracy, 35(4), 587-607. Retrieved from https://doi.org/10.1177/0143831X13491842

Kainz, A. (2012). The influence of intercultural behaviour on business management. České Budejovice.

Kawano, T. (2015). Standardisation Strategy of the German Manufacturing Policy: Industrie 4.0. Journal of the Robotics Society of Japan, 33(5), 318-324. Retrieved from https://doi.org/10.7210/jrsj.33.318

Kratochvíl, O., Cícha, P. and Jurča, R. (2017). Digitální technologie a čtvrtá průmyslová revoluce. Evropský polytechnický institut, s.r.o.

Löwisch, M., Caspers, G. and Klumpp, S. (2019). Arbeitsrecht: Ein Studienbuch (12th ed.). Vahlen.

Mařík, V. (2016). Průmys/ 4.0: výzva pro Českou republiku. Management Press.

Rohrbach, T. (2017). Deutsche Wirtschaft hält sich für Industrie 4.0-Weltmeister. Retrieved from http://www.staufen.ag/de/news-

events/news/article/2014/10/studie-deutsche-wirtschaft-\%0Ahaelt-sich-fuerindustrie-40-weltmeister.html\%0A.

Schhmann, I. (2014). Labour Law Reforms in Europe: Adjusting Employment Protection Legislation for the Worse? SSRN Electronic Journal, 5-59. Retrieved from https://doi.org/10.2139/ssrn.2512678

Steiner, J. and Woods, L. (2009). EU Law (10th ed.). Oxford University Press.

Tomek, G. and Vávrová, V. (2017). Průmys/ 4.0 aneb Nikdo sám nevyhraje. Průhonice: Professional Publishing.

Werro, F. and Dedek, H. (2017). What We Write About When We Write About Comparative Law: Pierre Legrand's Critique in Discussion*Preface. The American Journal of Comparative Law, 65(suppl_1), vii-x. Retrieved from https://doi.org/10.1093/ajcl/avx034 
